\title{
SSR Marker Based DNA Fingerprinting for Cowpea Varieties of Tamil Nadu [Vigna unguiculata (L.) Walp.]
}

\author{
S. Ragul, N. Manivannan, A. Mahalingam*, \\ V. Babu Rajendra Prasad and S. Lakshmi Narayanan
}
National Pulses Research Centre, Tamil Nadu Agricultural University Vamban, Pudukkottai - 622 303, Tamil Nadu, India

*Corresponding author

\section{A B S T R A C T}

\begin{tabular}{|l|}
\hline Ke y w or d s \\
Cowpea, SSR \\
Marker, DNA \\
fingerprinting
\end{tabular}

Keywords

Cowpea, SSR

Marker, DNA

fingerprintin

\section{Introduction}

Cowpea [Vigna unguiculata (L.) Walp.], Fabaceae, $(2 \mathrm{n}=2 \mathrm{x}=22)$ is an essential leguminous crop in less-developed countries of the tropics and subtropics, especially in sub-Saharan Africa, Asia and Latin America (Singh et al., 1997). Cowpea plays a major role in human nutrition not only because of its good protein quality with a high nutritional value. It provides strong support to the livelihood of small scale farmers through its contributions to their nutritional security, income generation and soil fertility enhancement. Worldwide about 6.5 million metric tons of cowpea are produced annually on about 14.5 million hectares. The low productivity of cowpea is attributable to numerous abiotic and biotic constraints. The abiotic stress factors comprise drought, low soil fertility and heat while biotic constraints include insects, diseases, parasitic weeds, and nematodes.

Progress has been made through conventional breeding at international and national research institutions in the last three decades towards the development of new varieties. Several morphological characters are available to differentiate the varieties. However appropriate growth stage is necessary to observe the differentiation. To overcome this 
problem some of the techniques have currently in the utilization. One among the proven technique is DNA fingerprinting technology. DNA fingerprinting technique was invented by Alec Jeffreys during 1985. While it is very difficult task to tell the differences in a crop variety simply just by the morphological descriptors, DNA fingerprinting makes it possible for researchers to pinpoint specific fingerprint and accurately identify crop varieties. Several research organizations in India and across the globe have started offering DNA testing for plant varietal identification. DNA fingerprinting is used by plant breeders of both private and public sectors for identification for crop varieties. More importantly, Protection of Plant Variety and Farmers Right Authority (PPV \& FRA, 2001), Govt. of India made a DNA fingerprint as an additional mandatory requirement for the release of new crop varieties released by the Variety Release Committee. With this background, an attempt was made in this study to identify a molecular marker to differentiate the newly released variety VBN 3 from the other ruling varieties of cowpea.

\section{Materials and Methods}

The experimental material comprises the new variety VBN 3 released from National Pulses Research Center, Vamban (Fig. 1) and check varieties viz., Vamban 1 and $\mathrm{CO}(\mathrm{CP}) 7$. The new variety $\mathrm{VBN} 3$ is a cross derivative between TLS 38 x VCP 16-1. The duration ranges from75-80 days and suitable for cultivation in June - July and September October season in Tamil Nadu. DNA fingerprinting work has carried out with a total of 25 markers. These were randomly selected from the SSR markers reported by Isemura et al., (2012) in mungbean (Table 1).

DNA extraction was performed using CTAB procedure suggested by Doyle and Doyle (1987) with modifications. Young leaves were collected and ground using CTAB buffer of $500 \mu \mathrm{l}$ with pinch of Poly Vinyl Pyrrolidone. Then the tubes were kept in water bath at $65^{\circ} \mathrm{C}$ for $30 \mathrm{~min}$. The sample were added with 500 $\mu 1$ of P: C: I (Phenol: Chloroform: Iso-amyl alcohol) in the ratio of $(25: 24: 1)$, centrifuged for about $10 \mathrm{~min}$ at $10000 \mathrm{rpm}$ and collected the supernatant. Again the supernatant was added with $400 \mu \mathrm{l}$ of $\mathrm{C}$ : I (Chloroform: Isoamyl alcohol in the ratio of 24:1). The tube was centrifuged for $5 \mathrm{~min}$ at $10000 \mathrm{rpm}$ and collected the supernatant without disturbing the bottom layer. Then it was added with 300 $\mu \mathrm{l}$ of $100 \%$ ethanol, kept in deep freezer at $4^{\circ} \mathrm{C}$ for $30 \mathrm{~min}$ and centrifuged for $10 \mathrm{~min}$ at $8000 \mathrm{rpm}$. The supernatant was discarded and allowed the pellets to air dry. The pellets were

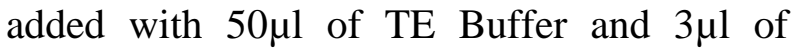
RNAase. The samples were kept in water bath for $30 \mathrm{~min}$ at $65^{\circ} \mathrm{C}$. Further the DNA was stored under $-20^{\circ} \mathrm{C}$ for future use.

The PCR profile starts with $94^{\circ} \mathrm{C}$ for $4 \mathrm{~min}$ followed by 30 cycles of denaturation at $94^{\circ} \mathrm{C}$ for 30 seconds, annealing at $55^{\circ} \mathrm{C}$ for 45 seconds and extension at $72^{\circ} \mathrm{C}$ for 1 minute. A final extension at $72^{\circ} \mathrm{C}$ for 20 minutes was included. The PCR was performed using thermocycler (Eppendorf, Germany). The final PCR product was electrophoresed using 3.5\% agarose gel with 100 bp ladder. Agarose gel was documented using GELSTAIN 4x advanced gel documentation unit (Medicare, India).

\section{Results and Discussion}

The major task in the varietal release program is the identification of distinguishable morphological characteristics for the newly released varieties. Distinguishing morphological traits for VBN 3 and check varieties were presented in Table 2 and Figure 2. Among the cowpea varieties, VBN 3 is clearly distinct from $\mathrm{CO}(\mathrm{CP}) 7$ for its leaf shape and seed shape. 
Table.1 List of primers and its sequences

\begin{tabular}{|c|c|c|}
\hline Primer codes & Forward/Reverse & Primer sequence 5'-3' \\
\hline \multirow[t]{2}{*}{ CEDG093 } & $\mathrm{F}$ & AAAACCCATGTAAAAGTTCA \\
\hline & $\mathrm{R}$ & СААТССАТТСССТТСТТААТ \\
\hline \multirow[t]{2}{*}{ CEDG128 } & $\mathrm{F}$ & CTGCCAAAGATGGACAACTTGGAC \\
\hline & $\mathrm{R}$ & GCCAACCATCATCACAGTGC \\
\hline \multirow[t]{2}{*}{ CEDG254 } & $\mathrm{F}$ & CGATGTCTCTTGCTTCAAGG \\
\hline & $\mathrm{R}$ & GTGAAGGACTAGCCAAGTTTG \\
\hline \multirow[t]{2}{*}{ CEDG136 } & $\mathrm{F}$ & GTTCCAAGTCTCCAATCCGTAC \\
\hline & $\mathrm{R}$ & CACTTCACTAGAACTGGTTCAG \\
\hline \multirow[t]{2}{*}{ CEDG244 } & $\mathrm{F}$ & GCATATAAGAAAAGCTTATCC \\
\hline & $\mathrm{R}$ & CTCTTGGAGTGATTTGATC \\
\hline \multirow[t]{2}{*}{ CEDG275 } & $\mathrm{F}$ & CACACTTCAAGGAACСТCAAG \\
\hline & $\mathrm{R}$ & GTAGGCAACCTCCATTGAAC \\
\hline \multirow[t]{2}{*}{ CEDG117 } & $\mathrm{F}$ & GTACACTTCCACTAATCCAAAATT \\
\hline & $\mathrm{R}$ & TGGTACCTTCCTTATCTGAAATTA \\
\hline \multirow[t]{2}{*}{ CEDG305 } & $\mathrm{F}$ & GCAGCTTCACATGCATAGTAC \\
\hline & $\mathrm{R}$ & GAACTTAACTTGGGTTGTCTGC \\
\hline \multirow[t]{2}{*}{ CEDG139 } & $\mathrm{F}$ & CAAACTTCCGATCGAAAGCGCTTG \\
\hline & $\mathrm{R}$ & GTTTCTCСТCAАTCTCAAGCTCCG \\
\hline \multirow[t]{2}{*}{ CP04320 } & $\mathrm{F}$ & GTTTTCCAGTTTTCTGCATTCCAAC \\
\hline & $\mathrm{R}$ & AACCATCAGCTTTCCTTTCAGACA \\
\hline \multirow[t]{2}{*}{ CEDG132 } & $\mathrm{F}$ & GGGTGTAATCCGTCAGAGGC \\
\hline & $\mathrm{R}$ & СТTCССССТCTTCCGTTCTC \\
\hline \multirow[t]{2}{*}{ CEDG171 } & $\mathrm{F}$ & CTTGAGAACCAACTCGAACTTC \\
\hline & $\mathrm{R}$ & GGGAAATCGAAGAGGGACAG \\
\hline \multirow[t]{2}{*}{ CEDG191 } & $\mathrm{F}$ & CAATAAGCAATCTGTGGAGAG \\
\hline & $\mathrm{R}$ & CTGCAGGAAACTTGGAATTGC \\
\hline \multirow[t]{2}{*}{ CEDG245 } & $\mathrm{F}$ & GATAGAGCTTAAACCCTC \\
\hline & $\mathrm{R}$ & CTTTTGATGACAAATGCC \\
\hline \multirow[t]{2}{*}{ CEDG174 } & $\mathrm{F}$ & GAGGGATCTCCAAAGTTCAACGG \\
\hline & $\mathrm{R}$ & GAAGGCTCCGAAGTTGAAGGTTG \\
\hline \multirow[t]{2}{*}{ CEDG111 } & $\mathrm{F}$ & TGGAAGTTTCCAAGAGGGTTTTC \\
\hline & $\mathrm{R}$ & ТСТСАССАССТТТТАССТТСТСА \\
\hline \multirow[t]{2}{*}{ CEDG176 } & $\mathrm{F}$ & GGTAACACGGGTTCAGATGCC \\
\hline & $\mathrm{R}$ & CAAGGTGGAGGACAAGATCGG \\
\hline \multirow[t]{2}{*}{ CEDG156 } & $\mathrm{F}$ & CGCGTATTGGTGACTAGGTATG \\
\hline & $\mathrm{R}$ & CTTAGTGTTGGGTTGGTCGTAAGG \\
\hline \multirow[t]{2}{*}{ CEDG092 } & $\mathrm{F}$ & TCTTTTGGTTGTAGCAGGATGAAC \\
\hline & $\mathrm{R}$ & TACAAGTGATATGCAACGGTTAGG \\
\hline \multirow[t]{2}{*}{ CP09781 } & $\mathrm{F}$ & CTGACGCATTCAGCATTTTACAGC \\
\hline & $\mathrm{R}$ & GGAAATACGGTTGCGTCCATGTAT \\
\hline \multirow[t]{2}{*}{ CEDG008 } & $\mathrm{F}$ & AGGCGAGGTTTCGTTTCAAG \\
\hline & $\mathrm{R}$ & GCCCATATTTTTACGCCCAC \\
\hline \multirow[t]{2}{*}{ CEDG141 } & $\mathrm{F}$ & CCAGGCATCCATGATGACC \\
\hline & $\mathrm{R}$ & GAAGTTGTTGGTAATGGTTGCCTC \\
\hline CEDG198 & $\mathrm{F}$ & CAAGGAAGATGGAGAGAATC \\
\hline & $\mathrm{R}$ & CCTTCTAAGAACAGTGACATG \\
\hline CEDG127 & $\mathrm{F}$ & GGTTAGCATCTGAGCTTCTTCGTC \\
\hline & $\mathrm{R}$ & CTCCTCACTTGGTCTGAAACTC \\
\hline CEDG020 & $\mathrm{F}$ & TATCCATACCCAGCTCAAGG \\
\hline & $\mathrm{R}$ & GCCATACCAAGAAAGAGG \\
\hline
\end{tabular}


Table.2 Distinguishing morphological traits for cowpea varieties

\begin{tabular}{|r|l|l|l|l|}
\hline S. No & Morphological traits & \multicolumn{1}{|c|}{ Vamban 1 } & \multicolumn{1}{|c|}{ VBN 3 } & \multicolumn{1}{c|}{ CO(CP)7 } \\
\hline 1. & Flower colour & Yellowish white & Light purple & Light purple \\
\hline 2. & Leaf shape & Sub globose & Sub globose & Sub hastate \\
\hline 3. & Seed colour & Creamy white & Light brown & Brown \\
\hline 4. & Seed shape & Kidney & Kidney & Rhomboid \\
\hline
\end{tabular}

Table.3 Polymorphic primers for the varieties Vamban 1, VBN 3 and $\mathrm{CO}(\mathrm{CP}) 7$ with base pair differences

\begin{tabular}{|c|c|c|c|}
\hline \multirow{2}{*}{ Primers/varieties } & \multicolumn{3}{|c|}{ Base pair differences (bp) } \\
\hline Vamban 1 & VBN 3 & CO(CP)7 \\
\hline CEDG156 & 185 & 195 & 185 \\
\hline CP09781 & 290 & 260 & 300 \\
\hline CEDG171 & 195 & 205 & 205 \\
\hline CEDG127 & 260 & 260 & 290 \\
\hline CEDG008 & 110 & 130 & 130 \\
\hline CEDG305 & 130 & 130 & 120 \\
\hline
\end{tabular}

Fig.1 Field view of VBN 3

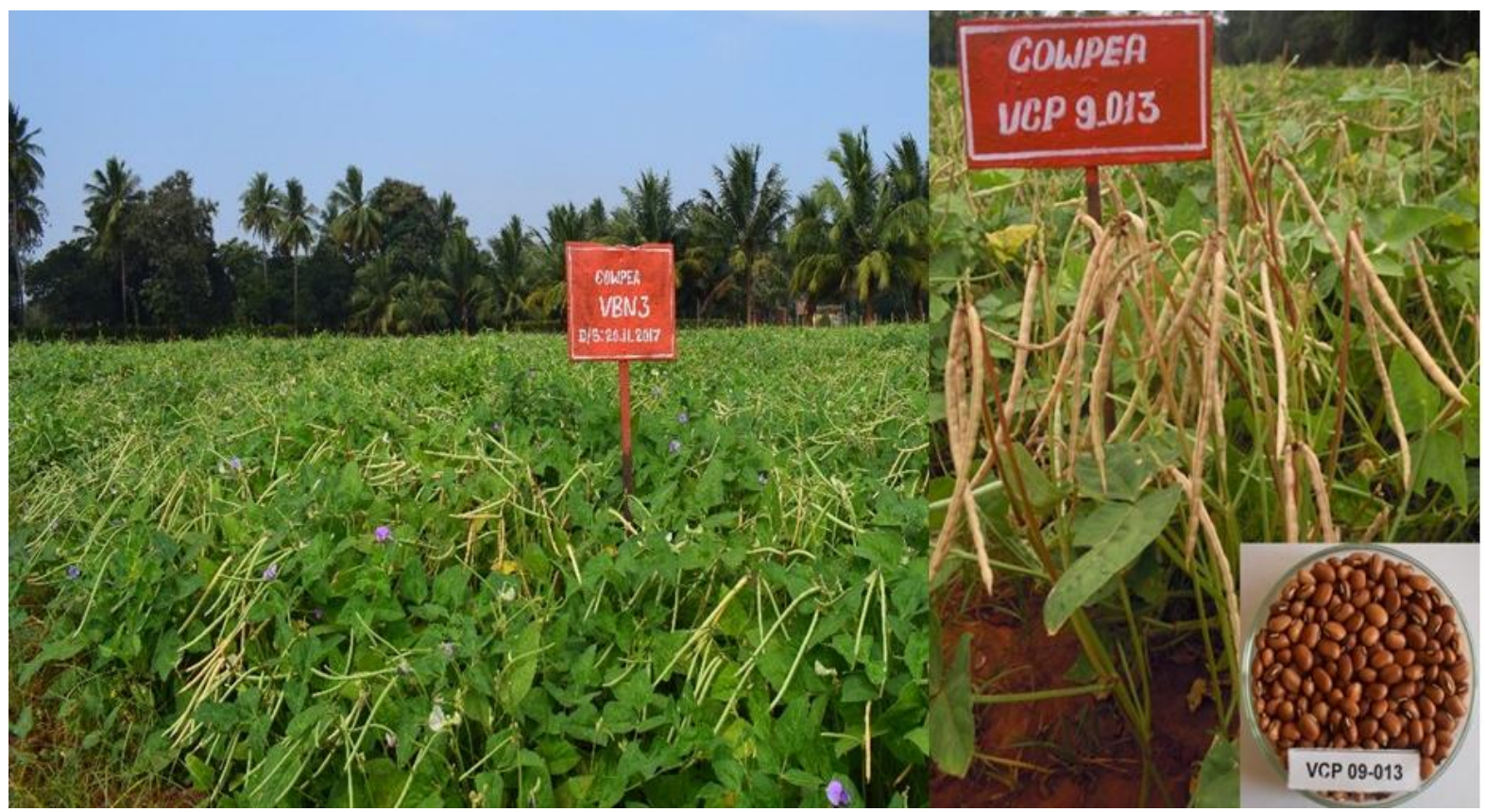


Fig.2 Morphological differences among cowpea varieties: a) Flower colour; b) Leaf shape; c) Seed colour and d) Seed shape

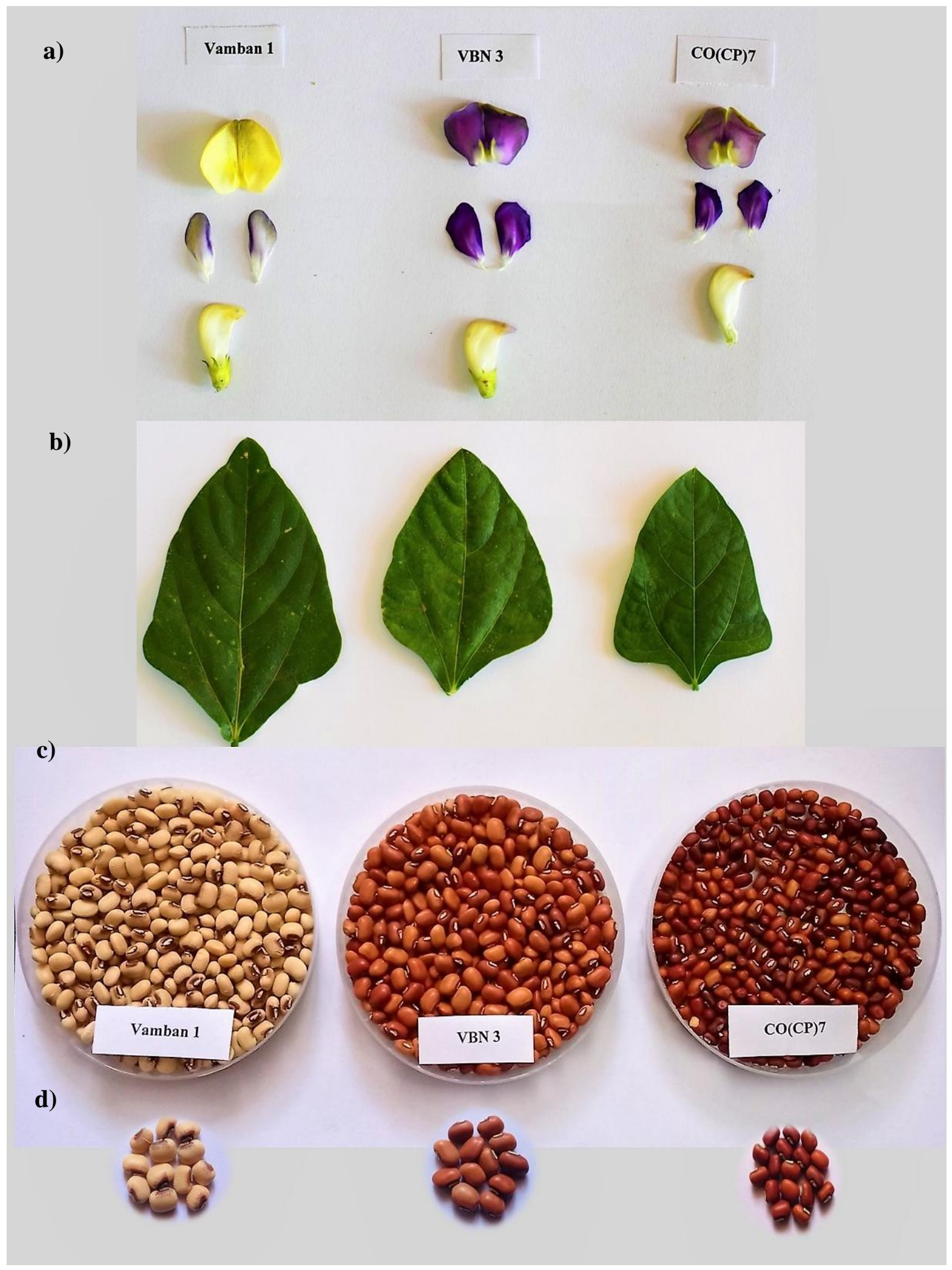


Fig.3 DNA fingerprinting for varieties Vamban 1, VBN 3 and $\mathrm{CO}(\mathrm{CP}) 7$

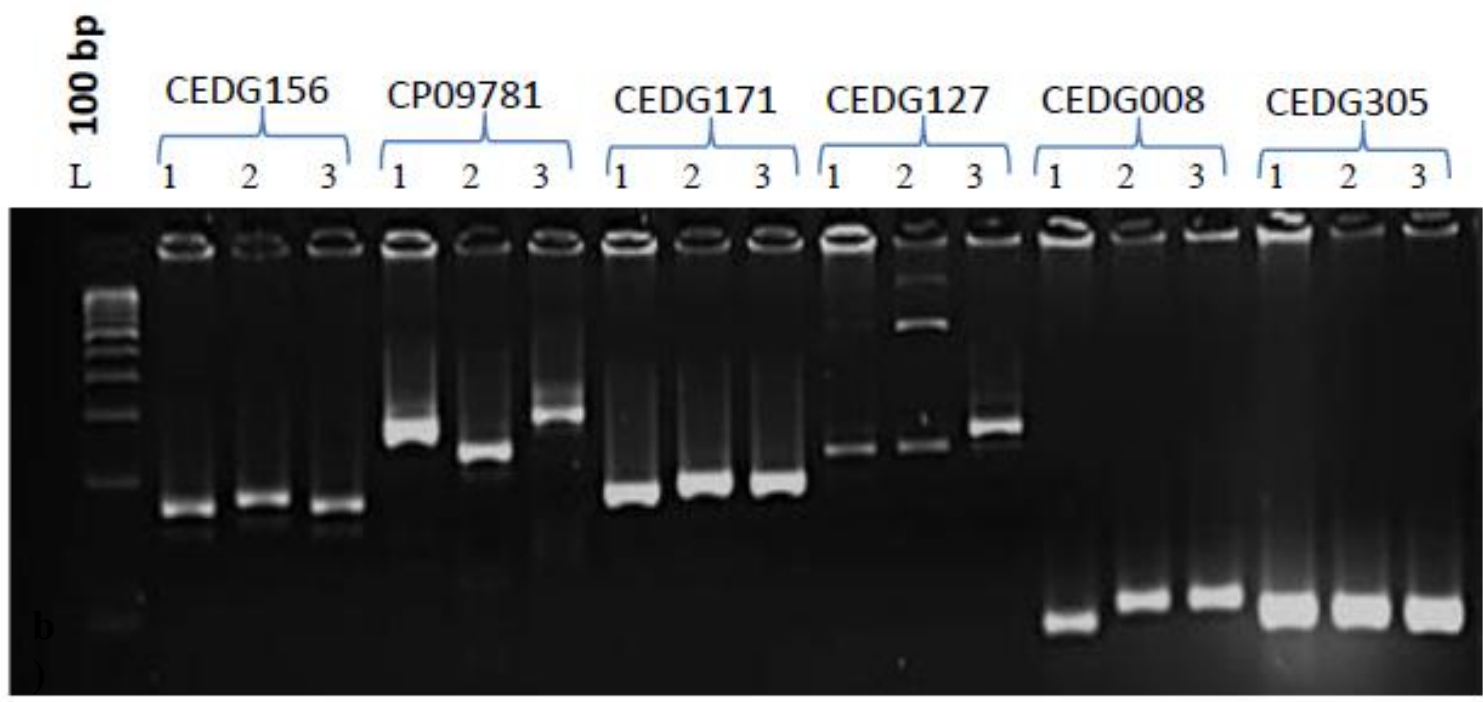

1-Vamban 1; 2-VBN 3; 3-CO(CP) 7

The variety VBN 3 has sub globose leaf shape and kidney seed shape. However the variety $\mathrm{CO}(\mathrm{CP}) 7$ has sub hastate leaf shape and rhomboid seed shape. Vamban 1 has similar leaf shape and seed shape of VBN 3. Likewise, VBN 3 can be differentiated from Vamban 1 for flower colour and seed colour. Variety VBN 3 has light purple and light brown as flower and seed colour respectively. While the variety Vamban 1 has yellowish white flower and creamy white seed colour. VBN 3 and $\mathrm{CO}(\mathrm{CP}) 7$ has similar flower colour and $\mathrm{CO}(\mathrm{CP}) 7$ has brown seed colour.

Distinguishing the closely related varieties is a difficult task. In that case morphological descriptors will lose its utility as it has limited classifications. Hence molecular level varietal differentiation has gained its importance for the varietal identification. DNA fingerprinting will be a better choice of obtaining clear differences to pinpoint the particular variety.

A total of $25 \mathrm{SSR}$ primers were used to differentiate VBN 3 from Vamban 1 and $\mathrm{CO}(\mathrm{CP}) 7$. These primers were selected from
11 linkage groups of mungbean reported by Isemura et al., (2012). Among the primers six primers viz., CEDG156, CP09781, CEDG171, CEDG127, CEDG008 and CEDG 305 had polymorphism among varieties (Table 3 and Fig. 3). Primers CEDG156, CP09781, CEDG171 and CEDG008 had polymorphism between Vamban 1 and VBN3. Likewise, primers CEDG 156, CP09781, CEDG127 and CEDG305 had polymorphism between VBN3 and $\mathrm{CO}(\mathrm{CP}) 7$. One primer, $\mathrm{CP} 09781$ was able to differentiate all three varieties. Hence these primers may be useful to differentiate these varieties at DNA level. This can be a potent tool in seed certification to find out the genetic purity at seed lot inspection itself.

To conclude, morphological descriptors are available to distinguish the varieties Vamban 1, VBN 3 and $\mathrm{CO}(\mathrm{CP}) 7$. However, all these varieties cannot be distinguished with a single character alone. The DNA marker will be an added tool to distinguish varieties. Out of 25 primers tested, six primers were useful to aid in DNA fingerprinting to differentiate these varieties. Among these, CP09781 can able to 
differentiate all the three varieties. These markers will be a potent tool in seed certification.

\section{References}

Shivakumar, M., Gireesh, C., and Ramesh, S. V. 2014. DNA Finger Printing - A Tool for Identification of Cultivars. Pop. KHETI, 2, 160-162.

Muchero, W., Diop, N. N., Bhat, P. R., Fenton, R. D., Wanamarker, S., Pottorff, M., Hearne, S., Cisse, N., Fatokun, C., Ehlers, J. D., Roberts, P. A., and Close, T. J. 2009. A consensus genetic map of cowpea [ Vigna unguiculata (L) Walp.] and synteny based on EST-derived SNPs. PNAS, 106, 18159-18164.

Morell, M. K., Peakall, R., Appeals, R., Preston, L. R., and Lloyd, H. L. 1995. DNA profiling techniques for plant variety identification. Aust. J. Exp. Agric., 35, 807-19.

Badiane, F. A., Gowda, B. S., Cissé, N., Diouf, D., Sadio, O., and Timko, M. P. 2012. Genetic relationship of cowpea (Vigna unguiculata) varieties from Senegal based on SSR markers. Genet. Mol. Res., 95: 292-304.

Boukar, O., Fatokun, C. A., Huynh, B., and Roberts, P. A. 2006. Genomic Tools in Cowpea Breeding Programs : Status and Perspectives. Front. Plant Sci., 7: 1-13.

Asare, A. T., Gowda, B. S., Galyuon, I. K. A., Aboagye, L. L., Takrama, J. F., and Timko, M. P. 2010. Assessment of the genetic diversity in cowpea (Vigna unguiculata L. Walp.) germplasm from Ghana using simple sequence repeat markers. NIAB, 8: 142-150.

Chakravarthi, B. K. and Naravaneni, R. 2006. SSR marker based DNA fingerprinting and diversity study in rice (Oryza sativa. L). African J. Biotechnol., 5: 684-688.

Archak, S., Gaikwad, A. B., Gautam, D., Rao, E. V. V. B., Swamy, K. R. M., and Karihaloo, J. L. 2003. DNA fingerprinting of Indian cashew (Anacardium occidentale L.) varieties using RAPD and ISSR techniques. Euphytica, 230: 397-404.

Agbicodo, E. M., Fatokun, C. A., and Bandyopadhyay, R. 2010. Identification of markers associated with bacterial blight resistance loci in cowpea [ Vigna unguiculata (L.) Walp.]. Euphytica, 175: 215-226.

Isemura, T., Kaga, A., and Tabata, S. 2012. Construction of a genetic linkage map and genetic analysis of domestication related traits in Mungbean (Vigna radiata). PLoS One, 7: e41304.

Singh, B. B., Chambliss, O. L., Sharma, B. 1997. Recent advances in cowpea breeding. Advances in cowpea research. IITA and Japan International Research Center for Agricultural Sciences (JIRCAS), Ibadan, Nigeria 30-49.

Doyle, J. J. and J. L. Doyle. 1987. A rapid DNA isolation procedure for small quantities of fresh leaf tissue. Phytochemical Bulletin, 19: 11-15.

\section{How to cite this article:}

Ragul, S., N. Manivannan, A. Mahalingam, V. Babu Rajendra Prasad and Lakshmi Narayanan, S. 2018. SSR Marker Based DNA Fingerprinting for Cowpea Varieties of Tamil Nadu [Vigna unguiculata (L.) Walp.]. Int.J.Curr.Microbiol.App.Sci. 7(04): 641-647. doi: https://doi.org/10.20546/ijcmas.2018.704.072 